\title{
The Frequency of Spontaneous Vertebral Fracture in Geriatric Patients and the Relationship of Vertebral Fractures with Age: A Retrospective Study
}

\author{
Geriatrik Hastalarda Spontan Vertebral Fraktür Sıklığı ve Vertebral Fraktürün Yaşla ilişkisi: \\ Retrospektif Çalışma
}

(D) Zeynep Kılıç, (D) Berat Meryem Alkan*

Ankara City Hospital, Clinic of Physical Medicine and Rehabilitation, Ankara, Turkey *Ankara Yıldırım Beyazıt University Faculty of Medicine; Ankara City Hospital, Department of Physical Medicine and Rehabilitation, Ankara, Turkey

\section{Abstract}

Objective: Vertebral fractures impair the quality of life in the geriatric patients and increase their economic costs. In this study, we aimed to identify spontaneous vertebral fracture rates and associated risk factors in the elderly.

Materials and Methods: Patients over the age of 65 years who were admitted to our physical medicine and rehabilitation outpatient clinic with back pain between January 2018 and June 2018 were examined retrospectively. A total of 136 patients with thoracic and lumbar spine fractures were included in this study. Data regarding osteoporosis treatment, diabetes mellitus, chronic renal failure and thyroid dysfunctions as well as vitamin $D$ levels were recorded for all patients.

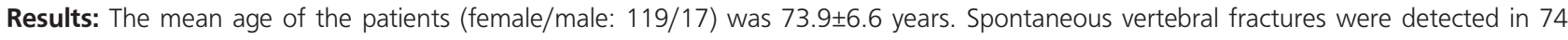
patients (54.4\%). Vertebral fractures were concentrated in the lower thoracic and upper lumbar regions. The patients were divided into the following two groups: Group 1 (65-74 years old) and group 2 ( $\geq 75$ years old). Moreover, the rate of vertebral fracture was significantly higher in group 2 than in group $1(p<0.05)$. Regression analysis revealed that age, female gender and the presence of osteoporosis were associated with vertebral fractures.

Conclusion: Vertebral fractures increase dramatically in geriatric patients. Furthermore, advanced age is an independent risk factor for vertebral fractures. Due to the high diagnostic and treatment costs as well as negative impacts of vertebral fractures on the quality of life, its diagnosis and treatment must be performed in a timely manner for the geriatric patients.

Keywords: Geriatrics, age, vertebrae, fracture, osteoporosis

\section{Öz}

Amaç: Vertebral kırıklar geriatrik hastalarda yaşam kalitesini bozmakta ve ekonomik maliyeti artırmaktadır. Bu çalısmada, geriatrik hastalarda spontan vertebral fraktür oranlarını ve risk faktörlerini belirlemeyi amaçladık.

Gereç ve Yöntem: 1 Ocak-30 Haziran 2018 tarihleri arasında fiziksel tıp ve rehabilitasyon polikliniğine dorsalji şikayeti ile başvuran 65 yaş üstü hastaların verileri retrospektif olarak incelendi. Torakal ve lomber omurga grafilerinde kırık saptanan 136 hasta çalışmaya alındı. Hastaların vitamin D düzeyi, osteoporoz tedavileri, diabetes mellitus, kronik böbrek yetersizliği ve tiroid disfonksiyonları kaydedildi.

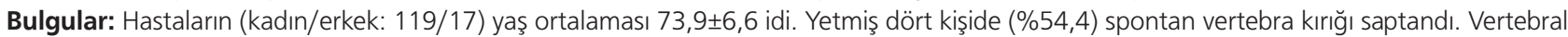
kırıklar, alt torasik ve üst lomber bölgede yoğunlaşmaktaydı. Hastalar grup 1; 65-74 yaş arası, grup 2; 75 yaş ve üstü hastalar olarak gruplara ayrıldı. Grup 2'deki spontan vertebra fraktür oranları istatistiksel olarak anlamlı derecede yüksekti $(p<0,05)$. Regresyon analizine göre yaş, kadın cinsiyet ve osteoporoz varlığı vertebral fraktür açısından belirgin risk faktörüydü.

Sonuç: Geriatrik hastalarda vertebral kırıklar dramatik şekilde artmaktadır. Ileri yaş (>75 yıl) vertebral kırıklar için majör ve bağımsız risk faktörüdür. Maliyetinin yüksek olması ve yaşam kalitesini olumsuz etkilemesi nedeniyle geriatrik hastalarda kemik kalitesine yönelik tanı ve tedavilerin zamanında yapılması gerekmektedir.

Anahtar kelimeler: Geriatri, yaş, vertebra, fraktür, osteoporoz

Address for Correspondence/Yazışma Adresi: Zeynep Kılıç MD, Ankara City Hospital, Clinic of Physical Medicine and Rehabilitation, Ankara, Turkey

Phone: +90 5323650927 E-mail: drzeynepk@yahoo.com ORCID ID: orcid.org/0000-0002-5537-0266

Received/Gelis Tarihi: 10.07.2020 Accepted/Kabul Tarihi: 20.10.2020

Presented in: This study was presented orally at the $6^{\text {th }}$ Medical Rehabilitation Congress on 6-11 November.

${ }^{\circ}$ Copyright 2021 by the Turkish Osteoporosis Society / Turkish Journal of Osteoporosis published by Galenos Publishing House. 


\section{Introduction}

Osteoporosis is a skeletal system disorder characterized by the deterioration of bone fragility and fracture probability as a result of degradation of low bone mass and bone micro-architecture. The bone matrix consists of mineral, collagen, water and a small amount of non-collagen proteins. Changes within these components or changes in the interaction between any or all of these components contribute to fracture (1).

The genetic predisposition is also important in the relationship between mechanical loading and bone strength concerning fracture. Two mechanical forces that affect the bone is gravity and muscle contraction. The ability of the bone to meet mechanical loading depends on bone mineral density (BMD), muscle mass and quality (2). The changes in muscle fascicule architecture and changes in volume are also very important for muscle strength. In old age, the sarcopenia and the skeletal muscles weaken and shrink (3). It was shown that the elderly experienced different dynamic spinal stiffness and loading compared to young adults for a functional lifting task (4). Osteoporotic vertebra fracture occurs when the forces applied to the vertebral body exceed the strength of the vertebrae. The person's height, weight, muscle strength, movement performance, spinal curvature, intervertebral disc, bone size, density, micro-architecture, collagen changes are factors affecting spine biomechanics $(5,6)$. The most common osteoporotic fractures in old age are a significant health problem as they lead to a decrease in quality of life, increased morbidity and mortality, all of which cause great economic costs $(7,8)$. Some of the risk factors identified for osteoporotic fractures include advanced age, decreased BMD, chronic inflammatory disease, endocrine system diseases [diabetes mellitus (DM), thyroid], glucocorticoid use, chronic renal and hepatic insufficiency, low vitamin D level, and smoking and alcohol use (9-12). Fractures are most commonly seen in the wrist, hip, humerus, pelvis, rib and the vertebra. The clinical features of non-vertebral fractures are noticeable at the time they occur. Unlike fractures in other skeletal areas, one-third of vertebral fractures are not clinically noticeable unless a spinal visualization is conducted $(12,13)$. When a vertebral fracture occurs, clinical pain, increased kyphosis, a decrease in respiratory capacity, gastroesophageal reflux, decreased physical activity and an increased risk of falling linked to balance disorder may be observed (12).

In this study, we aimed to identify spontaneous vertebral fracture rates and associated risk factors in elderly people.

\section{Materials and Methods}

The records of the patients over the age of 65 admitted to our physical therapy and rehabilitation polyclinic between 1 January-30 June 2018 with complaints of back pain were examined retrospectively through our hospital's computer record system. Within these dates, the records of 752 patients were examined. A total of 136 patients with thoracic and lumbar spine radiographs and fractures were included in the study.
Vertebral radiographs of patients were evaluated by researcher physicians. Presence of fractures in patients; T4-L5 in lateral spinal radiographs anterior, middle and/or posterior heights in intervertebrae $20 \%$ reduction in neighbouring vertebrae is defined as fracture evaluated by semicantitive method (6). Presence of fracture; lateral height in at least one vertebra between T4 and L5 in spinal radiographs it was determined by observing the loss (14). The patients' 25-hydroxyvitamin D levels, whether they were taking osteoporosis treatment, DM, chronic renal failure and thyroid dysfunctions were recorded.

The patients were divided into two groups according to the relationship between spontanous vertebral fractures and age. Group 1 was defined as the patients between 65-74 years of age and group 2 was defined as the patients at or above the age of 75 .

We excluded patients from the study whose data we could not access and who had a history of rheumatologic disease, malignancy and trauma.

The ethics committee approval for this study was made by Yıldırım Beyazıt University Faculty of Medicine Clinical Research Ethics Committee (decision no: 231, date: 24.10.2018). This study adheres to the ethical rules reported in the 1964 Helsinki Declaration, which were revised in 2013.

\section{Statistical Analysis}

Statistical analyses were made with the SPSS 22.0 package program. Following descriptive statistical analyses, Mann-Whitney $\mathrm{U}$ and Student t-tests were performed based on the distribution of the data in the cross-group comparison. The categorical data were analyzed with the chi-square or Fisher's Exact Test (when Levene's test was significant). Binary logistic regression analysis was performed with the logistic regression method. The independent variables (gender, age, 25-hydroxyvitamin $D_{3}$ level, osteoporosis treatment and comorbidity status) were included in the binary regression analysis. Presence of vertebra fracture was the dependent variable. The statistical significance of the results was evaluated at $p<0.05$. Post-hoc power analyses were performed with using $G{ }^{*}$ Power 3.0.10 program (Heinrich-Heine Universität, Düsseldorf, Düsseldorf, Germany) and power of the study (1- $\beta$ ) was calculated as 0.61 (alpha coefficient was accepted as 0.05, effect size was accepted 0.3).

\section{Results}

The mean age of 136 patients (female/male: 119/17) was 73.9 \pm 6.6 . A spontaneous vertebral fracture was detected in 74 people $(54.4 \%)$. Vertebral fractures were concentrated in the lower thoracic and upper lumbar region. In terms of the number of vertebral fractures, it was observed that $25.7 \%$ had $1,36.5 \%-2,13.5 \%-3,13.5 \%-4$ and $10.8 \%$ had 5 vertebral fractures. The average level of vitamin D was $22.3 \pm 13.4 \mathrm{mg} /$ $\mathrm{dL}$. The demographic and clinical features of the patients are shown in Table 1. When the patients were divided into two groups; 65-75 years of age and over 75, the spontaneous vertebral fracture rates were significantly higher in patients over 
the age of 75 than in patients aged 65-75 $(p<0.05)$. Differences were not found between the two groups in terms of gender, vitamin D level, osteoporosis treatment and systemic disease. The comparison of the fracture and clinical features of patients based on age groups is shown in Table 2. In binary logistic regression analysis, age [odds ratio (OR): 1.181, 95\% confidence interval (Cl): 1.031-1.352, $p<0.05]$, female gender (OR: 6.301,

Table 1. Demographic and clinical features of geriatric patients with back pain

\section{$\mathrm{n}=136$}

\begin{tabular}{|l|l|}
\hline Age $($ mean $\pm \mathrm{SD})$ & $73.9 \pm 6.6$ \\
\hline Female/male $\mathrm{n}(\%)$ & $119(87.5) / 17(12.5)$ \\
\hline Those with vertebral fractures $\mathrm{n}(\%)$ & $74(54.4)$ \\
\hline $\begin{array}{l}\text { Those having osteoporosis treatment } \\
\mathrm{n}(\%)\end{array}$ & $91(66.9)$ \\
\hline $25-(\mathrm{OH}) \mathrm{D}_{3}$ level $(\mathrm{ng} / \mathrm{mL})$ (mean $\left.\pm \mathrm{SD}\right)$ & $22.3 \pm 13.4$ \\
\hline Presence of systemic disease $\mathrm{n}(\%)$ & \multicolumn{2}{|l|}{} \\
\hline Diabetes mellitus $\mathrm{n}(\%)$ & $44(32.6)$ \\
\hline Thyroid dysfunction $\mathrm{n}(\%)$ & $27(19.9)$ \\
\hline Chronic kidney disease $\mathrm{n}(\%)$ & $32(23.5)$ \\
\hline Spread of vertebral fractures number \\
\hline T7 & 3 \\
\hline T8 & 12 \\
\hline T9 & 9 \\
\hline T10 & 14 \\
\hline T11 & 31 \\
\hline T12 & 33 \\
\hline L1 & 29 \\
\hline L2 & 25 \\
\hline L3 & 15 \\
\hline L4 & 9 \\
\hline L5 & 3 \\
\hline $25-(O H) D_{3}: 25$-hydroxyvitamin $\mathrm{D}_{3^{\prime}}$ SD: Standard deviation \\
\hline
\end{tabular}

95\% Cl: 1.678-23.655, p<0.05), and presence of osteoporosis (OR: $2.554,95 \% \mathrm{Cl}: 1.023-6.375, \mathrm{p}<0.05)$ were associated with vertebra fracture positivity (Table 3 ).

\section{Discussion}

The determination of the previous vertebral fractures provides important information in assessing the risk of fracture in patients. It provides a guide in the prevention of fractures and the shaping of treatment following fracture. The most important conclusion of this study is that the presence of unnoticeable vertebral fractures in individuals over the age of 65 is considerably high and, in particular, independent of other factors dramatically increasing in individuals over the age of 75 .

Contrary to fractures in other skeletal regions, it has been demonstrated by some studies that vertebral fractures were not clinically recognized unless a spinal scan was performed (12). In a study of 567 patients with an average age of 72 , it was reported that 143 patients (25.2\%) had a spontaneous radiographic vertebral fracture (15). Merle et al. (16) in their study on the vertebral fracture awareness of 45 females aged between 60-85 years and 53 male patients between the ages of $50-85$ years found that $48.89 \%$ of women and $64.15 \%$ of men indicated that they were unaware of the vertebral fracture of the body. In the study of Reniu et al. (15) an undiagnosed vertebral fracture was detected in a quarter of patients admitted with non-spinal fractures. In a study by Sanfélix-Genovés et al. (17) which evaluated 824 post-menopausal women in the 50-87 age range, the ratio of vertebral fractures was $21.4 \%$ and $46.3 \%$ for women over 75 years of age. Only $1.5 \%$ of women reported that they were aware of the vertebral fracture. In another study in which 232 post-menopausal women were evaluated in our country (age: 35-89), the vertebral fracture ratio was found to be $12.1 \%(18)$. In our study, the vertebral fracture rate was $54.4 \%$ in patients over 65 years of age, and the rate of fractures was high in patients over the age of 75, independent of gender. In a study on risk factors in osteoporotic vertebral fractures in our country, it was found that advanced age formed a

Table 2. Comparison of vertebral fracture and clinical features in geriatric patients according to age groups

\begin{tabular}{|c|c|c|c|}
\hline & $\begin{array}{l}\text { Group } 1(n=84) \\
\text { Patients in the } 65-75 \text { age } \\
\text { range }\end{array}$ & $\begin{array}{l}\text { Group } 2(n=52) \\
\text { Patients } 75 \text { years of age } \\
\text { and above }\end{array}$ & p-value \\
\hline $\begin{array}{l}\text { Gender } \\
\text { Female/male } \mathrm{n}(\%)\end{array}$ & $\begin{array}{l}72 / 12 \\
(85.7 / 14.3)\end{array}$ & $\begin{array}{l}47 / 5 \\
(90.4 / 9.6)\end{array}$ & 0.424 \\
\hline 25-(OH) $\mathrm{D}_{3} \mathrm{mg} / \mathrm{dL}($ mean $\pm \mathrm{SD})$ & $22.0 \pm 14.4$ & $22.7 \pm 11.8$ & 0.456 \\
\hline $\begin{array}{l}\text { Patients receiving osteoporosis } \\
\text { treatment } \mathrm{n}(\%)\end{array}$ & $52(61.9)$ & $39(75)$ & 0.115 \\
\hline Presence of vertebral fracture n (\%) & $35(41.7)$ & $39(75)$ & $<0.05$ \\
\hline Presence of diabetes mellitus n (\%) & $26(30.9)$ & $18(34.6)$ & 0.657 \\
\hline Presence of thyroid disease $\mathrm{n}(\%)$ & $19(22.6)$ & $8(15.4)$ & 0.304 \\
\hline Presence of chronic renal failure $\mathrm{n}(\%)$ & $18(21.4)$ & $14(26.9)$ & 0.463 \\
\hline
\end{tabular}




\begin{tabular}{|c|c|c|c|}
\hline & OR & $95 \% \mathrm{Cl}$ & $\mathbf{p}$ \\
\hline Age & 1.181 & $1.031-1.352$ & 0.017 \\
\hline Gender (female) & 6.301 & $1.678-23.655$ & 0.006 \\
\hline $\begin{array}{l}\text { Presense of osteoporosis } \\
\text { treatment }\end{array}$ & 2.554 & $1.023-6.375$ & 0.045 \\
\hline Presense of comorbidity & 0.766 & $0.080-7.348$ & 0.817 \\
\hline $25-(\mathrm{OH}) \mathrm{D}_{3}$ & 1.303 & $0.507-3.346$ & 0.582 \\
\hline \multicolumn{4}{|c|}{$\begin{array}{l}\mathrm{R}^{2}=0.230\left(\mathrm{Cox} \& \text { Snell), } \mathrm{R}^{2}=0.307 \text { (Nagelkerke), }-2 \text { Log likelihood }=151,968,\right. \\
\text { model } \chi 2(2)=35,508, p<0.001, \chi 2=5.171, \text { degrees of freedom }=8, p=0.739 \\
\text { (Hosmer and Lemeshow test). OR: Odds ratio, Cl: Confidence interval, } 25-(\mathrm{OH}) \\
\mathrm{D}_{3}: 25 \text {-hydroxyvitamin } \mathrm{D}_{3}\end{array}$} \\
\hline
\end{tabular}

significantly high risk for vertebral fracture (19). A study where 15,570 patients from 19 European countries and 36 centres were radiographically evaluated, found that the vertebral deformity rate was similar in both sexes in all centres (in the range of $6.7 \%-20.2 \%$ in females and in the range $7.5 \%-19.8 \%$ for males) and its prevalence had been reported to increase with age in both sexes (20). Waterloo et al. (21) in a study of 2,887 patients in the age range of 30-87 years found that the proportion of vertebral fractures in women is $13.8 \%$ and $11.8 \%$ in males; $20.3 \%$ in men over the age of $70,19.2 \%$ in women, and indicated that they found a significant increase in vertebral fracture rate with age for both sexes. It was reported in a multicenter study that was conducted in Canada that age is the most significant determinant for vertebral fracture (22). In our study, the vertebral fracture rate in the $65-75$ age range was $41.7 \%$, and $75 \%$ over the age of 75 , and fractures increased with age in both sexes. These findings show a similarity to the data in the literature.

In the present study of ours, it was determined that female gender is a significant risk factor for osteoporosis and vertebral fractures. In the European Prospective Osteoporosis Study, it was reported that the incidence of vertebral fractures was higher in females at all age groups compared to males, and this increase was higher at a significant level over 75 years of age (23). In a study by Wáng et al. (24), future vertebral fractures risk in older females with or without osteoporotic vertebral fractures was found to be much higher compared to older males. In a study conducted in 12 countries to examine age and sex-specific non-traumatic fractures, it was reported that vertebral fracture was much more common in females (25).

Decreased BMD and vitamin $D$ deficiency were defined as risk factors for vertebral fracture in the elderly (12). Waterloo et al. (21) reported that low BMD was a risk factor for vertebral fracture in both sexes. The study of Reniu et al. (15) shows that $49.5 \%$ of vertebral fractures have osteoporosis. In another study comparing patients with and without vertebral fractures, it was found that both groups were similar in terms of age, BMD and systemic disease and that the lumbar T-score was significantly lower in those with the fractures (18). In a study that was conducted by Kanis et al. (26), it was determined that vertebral fracture risk was 9-12-fold more in individuals with low BMD. When Demirdal et al. (27) evaluated the rate of vertebral fracture in patients with osteoporosis, they found that the vertebral fracture rate was $18.9 \%$ in patients with primary osteoporosis and $18.2 \%$ in secondary osteoporosis. Imai et al. (13) which evaluated the fracture incidence of 337 patients over 65 years of age, reported that fracture incidence with patients on osteoporosis treatment is lower (14.5\%) and that there is a significant increase in vertebrae and hip fractures in the 70-89 age range. In our study, we found that vertebral fractures were more in individuals who received osteoporosis treatment, i.e. those with osteoporosis, independently from other variables.

Tamaki et al. (28) with their 15-year study where they screened 1,211 women over 50 years of age without early menopause and/or any condition affecting bone metabolism, found that vertebral fracture was significantly higher in patients with a level of vitamin $D<20 \mathrm{ng} / \mathrm{dL}$ compared to those with a vitamin D level $>20$. In another study focusing on the relationship between vertebral fracture and vitamin $D, 246$ back pain patients of an average age of 69 who had a vertebral fracture had their vitamin $D$ levels compared to 392 non-fracture back pain patients with an average age of 63. The level of vitamin $D$ in those with vertebral fractures was found to be significantly lower (29).

In our study, $66.9 \%$ of our patients were under treatment for osteoporosis and the average vitamin D level was $22.29 \mathrm{ng} / \mathrm{dL}$. We were unable to access information on whether our patients obtained vitamin D and BMD level control, before or after the fracture occurred. However, considering the age group, and the fact that the awareness of osteoporosis has increased in our country only over the last 15-20 years, we can conclude that the patients may be late in the initiation of osteoporosis treatment. Studies of anatomical regions where vertebral fractures are frequently seen have shown that the fractures are frequently reported in the lower thoracic and upper lumbar region $(17,29)$. In our study, fractures were similarly concentrated in the lower thoracic and upper lumbar region. In our study, $74.3 \%$ of patients with vertebral fracture had multiple fractures. In many studies, it has been shown that the risk of re-fracture in patients with osteoporotic vertebral fractures is high and that it increases with age $(15,30)$.

It has been shown by various studies that some systemic diseases impact bone metabolism, which is negatively influenced by numerous different mechanisms that increase the risk of osteoporosis and fracture. DM, chronic kidney disease, thyroid diseases are some of these (9-12). Similar to the literature findings, our study found that $32.35 \%$ of patients with vertebral fractures suffered from DM, 19.85\% from thyroid disease and $23.52 \%$ had chronic kidney disease. When we compared our groups of patients with regard to these diseases, we did not detect any statistically significant difference in terms of systemic diseases. 
Osteoporotic vertebral fractures that disrupt the quality of life in the elderly and increase mortality also result in large economic costs $(12,31)$. The prevention of osteoporotic fractures is possibly by supporting bone quality, diagnosing and treating secondary causes, providing support for muscle mass to counter increased sarcopenia and posture disorders with ageing, treating balance disorders and reducing the risk of falling.

\section{Study Limitations}

The present study has some limitations. Since it was a retrospective study, muscle weakness, diet, agreement with the osteoporosis, medication that cause osteoporosis, and menopause time, which are the risk factors for vertebral fractures and osteoporosis, could not be evaluated. In our country, studies conducted on vertebral fracture rates in geriatric people are very few. In this respect, contributing to the literature is the strength of the present study.

\section{Conclusion}

The incidence of vertebral fracture increases rapidly as age progresses. In our study, we found that this increase, independent of other vertebral fracture risk factors, was more prevalent over the age of 75. Presence of osteoporosis and female gender are significant risk factors for vertebral fractures. Due to the high morbidity, cost and negative impact on quality of life, the diagnosis and bone quality treatments in the elderly must be made timely. Together with the non-neglect of posture and balance exercises, precautions must also be taken to reduce the risk of falling.

\section{Ethics}

Ethics Committee Approval: The ethics committee approval for this study was made by Yıldırım Beyazıt University Faculty of Medicine Clinical Research Ethics Committee (decision no: 231, date: 24.10 .2018$)$. This study adheres to the ethical rules reported in the 1964 Helsinki Declaration, which were revised in 2013.

Informed Consent: Retrospective study.

Peer-review: Externally and internally peer-reviewed.

\section{Authorship Contributions}

Surgical and Medical Practices: Z.K., B.M.A., Concept: Z.K., B.M.A., Design: Z.K., B.M.A., Data Collection or Processing: Z.K., B.M.A., Analysis or Interpretation: Z.K., B.M.A., Literature Search: Z.K., Writing: Z.K.

Conflict of Interest: No conflict of interest was declared by the authors.

Financial Disclosure: The authors declared that this study has received no financial support.

\section{References}

1. Burr DB. Changes in bone matrix properties with aging. Bone 2019;120:85-93

2. Frost HM. Bone's mechanostat: a 2003 update. Anat Rec A Discov Mol Cell Evol Biol 2003:275:1081-101.
3. McGill SM, Hughson RL, Parks K. Changes in lumbar lordosis modify the role of the extensor muscles. Clin Biomech (Bristol, Avon) 2000;15:777-80.

4. Christiansen BA, Bouxsein ML. Biomechanics of vertebral fractures and the vertebral fracture cascade. Curr Osteoporos Rep 2010:8:198-204.

5. Singh DK, Bailey M, Lee RY. Ageing modifies the fibre angle and biomechanical function of the lumbar extensor muscles. Clin Biomech (Bristol, Avon) 2011;26:543-7.

6. Quirk DA, Hubley-Kozey CL. Age-related changes in trunk neuromuscular activation patterns during a controlled functional transfer task include amplitude and temporal synergies. Hum Mov Sci 2014;38:262-80.

7. Ratti C, Vulcano E, La Barbera G, Canton G, Murena L, Cherubino P. The incidence of fragility fractures in Italy. Aging Clin Exp Res 2013;25 Suppl 1:S13-4

8. Hirsch JA, Beall DP, Chambers MR, Andreshak TG, Brook AL, Bruel $B M$, et al. Management of vertebral fragility fractures: a clinical care pathway developed by a multispecialty panel using the RAND/UCLA Appropriateness Method. Spine J 2018;18:215261.

9. Starup-Linde J, Hygum K, Langdahl BL. Skeletal Fragility in Type 2 Diabetes Mellitus. Endocrinol Metab (Seoul) 2018;33:339-51.

10. Fusaro M, Aghi A, Mereu MC, Giusti A. Fratture da fragilità nella Malattia Renale Cronica (MRC) [Fragility fracture in the Chronic Kidney Disease (CKD)]. G Ital Nefrol 2017;34:2017-vol6.

11. Williams GR, Bassett JHD. Thyroid diseases and bone health. J Endocrinol Invest 2018;41:99-109.

12. Schousboe JT. Epidemiology of Vertebral Fractures. J Clin Densitom 2016;19:8-22

13. Imai N, Endo N, Shobugawa Y, Oinuma T, Takahashi $Y$, Suzuki K, et al. Incidence of four major types of osteoporotic fragility fractures among elderly individuals in Sado, Japan, in 2015. J Bone Miner Metab 2019;37:484-90.

14. Genant HK, Wu CY, van Kuijk C, Nevitt MC. Vertebral fracture assessment using a semiquantitative technique. J Bone Miner Res 1993;8:1137-48

15. Reniu AC, Ong T, Ajmal S, Sahota O. Vertebral fracture assessment in patients presenting with a non-hip non-vertebral fragility fracture: experience of a UK Fracture Liaison Service. Arch Osteoporos 2017;12:23.

16. Merle B, Dupraz C, Haesebaert J, Barraud L, Aussedat M, Motteau $C$, et al. Osteoporosis prevention: where are the barriers to improvement in a French general population? A qualitative study. Osteoporos Int 2019;30:177-85

17. Sanfélix-Genovés J, Reig-Molla B, Sanfélix-Gimeno G, Peiró S, Graells-Ferrer M, Vega-Martínez M, et al. The population-based prevalence of osteoporotic vertebral fracture and densitometric osteoporosis in postmenopausal women over 50 in Valencia, Spain (the FRAVO study). Bone 2010;47:610-6.

18. Kilincer C, Kabayel DD, Cagli B, Unlu E, Wicki B, Ozdemir F. Frequency, distribution and severity of prevalent osteoporotic vertebral fractures in postmenopausal women. Turk Neurosurg 2013;23:476-83.

19. Günaydın R, Ölmez N, Kaya T, Vidinli BD, Memiş A. Osteoporotik Vertebra Fraktürlerinde Risk Faktörleri. Turk J Osteoporos 2002:8:105-9.

20. O'Neill TW, Felsenberg D, Varlow J, Cooper C, Kanis JA, Silman AJ. The prevalence of vertebral deformity in european men and women: the European Vertebral Osteoporosis Study. J Bone Miner Res 1996;11:1010-8

21. Waterloo S, Ahmed LA, Center JR, Eisman JA, Morseth B, Nguyen $N D$, et al. Prevalence of vertebral fractures in women and men in the population-based Tromsø Study. BMC Musculoskelet Disord 2012;13:3.

22. Prior JC, Langsetmo L, Lentle BC, Berger C, Goltzman D, Kovacs CS, et al. Ten-year incident osteoporosis-related fractures in the population-based Canadian Multicentre Osteoporosis Study comparing site and age-specific risks in women and men. Bone 2015:71:237-43. 
23. European Prospective Osteoporosis Study (EPOS) Group Felsenberg $D$, Silman AJ, Lunt M, Armbrecht G, Ismail AA, et al. Incidence of vertebral fracture in europe: results from the European Prospective Osteoporosis Study (EPOS). J Bone Miner Res 2002;17:716-24.

24. Wáng YXJ, Che-Nordin N, Deng M, Griffith JF, Leung JCS, Kwok $A W L$, et al. Elderly males with or without existing osteoporotic vertebral fracture have much lower future vertebral fracture risk than elderly females: the MrOS (Hong Kong) year-4 follow-up spine radiograph study. Osteoporos Int 2019;30:2505-14.

25. Wade SW, Strader C, Fitzpatrick LA, Anthony MS. Sex- and age-specific incidence of non-traumatic fractures in selected industrialized countries. Arch Osteoporos 2012;7:219-27.

26. Kanis JA, Johnell O, Oden A, Borgstrom F, Zethraeus N, De Laet $C$, et al. The risk and burden of vertebral fractures in Sweden. Osteoporos Int 2004;15:20-6.

27. Demirdal US, Yigit I, Solak O, Toktaş H, Dundar U, Kavuncu V. The relationship between vertebral fractures and quality of life in patients with osteoporosis. Göztepe Tıp Dergisi 2010;25:20-4.
28. Tamaki J, Iki M, Sato Y, Kajita E, Nishino H, Akiba T, et al. Total 25-hydroxyvitamin $D$ levels predict fracture risk: results from the 15-year follow-up of the Japanese Population-based Osteoporosis (JPOS) Cohort Study. Osteoporos Int 2017;28:1903-13.

29. Maier GS, Seeger JB, Horas K, Roth KE, Kurth AA, Maus U. The prevalence of vitamin $D$ deficiency in patients with vertebral fragility fractures. Bone Joint J 2015;97-B:89-93.

30. Balasubramanian A, Zhang J, Chen L, Wenkert D, Daigle SG, Grauer $A$, et al. Risk of subsequent fracture after prior fracture among older women. Osteoporos Int 2019;30:79-92.

31. Abimanyi-Ochom J, Watts JJ, Borgström F, Nicholson GC, ShoreLorenti C, Stuart AL, et al. Changes in quality of life associated with fragility fractures: Australian arm of the International Cost and Utility Related to Osteoporotic Fractures Study (AusICUROS). Osteoporos Int 2015;26:1781-90. 